\title{
THE NON-CARNIVOROUS LEAF OF DARLINGTONIA CALIFORNICA
}

\section{JOHN BRITTNACHER・Ashland, Oregon・USA・john@carnivorousplants.org}

Keywords: Physiology: Darlingtonia californica leaf structure.

It is well known that Darlingtonia californica has two types of carnivorous leaves (Goebel 1891; Lloyd 1942). The juvenile carnivorous leaves consist of a long tube with a narrow, tongue-like extension that quite often curves down toward if not to the ground (Front Cover). The adult carnivorous leaves are a hooded tube with a fish tail or mustache-like extension. Large juvenile leaves can also be found on stolons or underground runners from adult plants. Horizontal small adult leaves can be found on juvenile plants. Developmentally, the juvenile leaves are not just simplified adult leaves (Franck 1976). Each type of leaf is adapted to a different set of prey.

What is not well known is Darlingtonia makes a flat, linear-lanceolate leaf as the first true leaf after the cotyledons in seedlings. I believe this linear-lanceolate leaf is not carnivorous because there are no obvious glands. Lloyd (1942) and Franck (1976) saw this leaf in their plants but interpreted it as a third cotyledon. It is not a cotyledon (Fig. 1). The leaf emerges after the cotyledons and its base wraps the apex inside the ring of cotyledons. Goebel (1891) recognized this leaf for what it is and noted it is the only case he knew of where such a leaf is produced within the Sarraceniaceae. It is also the only case I know of. The first true leaf produced by Sarracenia seedlings and all Heliamphora I am aware of, is a pitcher. The phyllodia of Sarracenia are not analogous to this Darlingtonia leaf. Sarracenia phyllodia are pitcher-derived, unifacial leaves (both sides are technically the outer facing, abaxial side of the leaf). Phyllodia are not normally produced in juvenile Sarracenia.

At first glance it would appear bizarre that Darlingtonia would maintain the developmental program to produce this third type of leaf. However, if this is the ancestral leaf then it could be present because the developmental program to produce a pitcher initiates after the leaf forms. To test this, 541 seedlings were observed, checking for plants that deviated from the first true leaf being linearlanceolate and the second true leaf a pitcher. The results are shown in Table 1 and images of aberrant plants are in Fig. 2, Back Cover, and Brittnacher (2014). Among the Del Norte County, California, seedlings, $1 \%$ had three cotyledons and $1 \%$ had a leaf configuration different from typical. The Siskiyou County, California, seedlings had $4 \%$ with three cotyledons and $5 \%$ with atypical leaf configurations. About $1 \%$ of seedlings started pitcher development earlier than typical either producing a pitcher as the first true leaf or producing a leaf intermediate between a linear-lanceolate leaf and

Table 1. Presence of leaf types in seedling Darlingtonia californica. The Del Norte Co. seeds were from 3 locations. The Siskiyou Co. seeds were from one location. All the locations were on mountains although the Del Norte Co. locations were about $600 \mathrm{~m}$ elevation while the Siskiyou Co. location was 2000 m elevation. The numbers are too small to determine statistical significance between the locations.

\begin{tabular}{|c|c|c|c|c|c|c|c|c|}
\hline \multirow[b]{2}{*}{ County } & \multicolumn{2}{|c|}{ Cotyledons } & \multicolumn{3}{|c|}{ First true leaf } & \multicolumn{3}{|c|}{ Second true leaf } \\
\hline & Two & Three & Linear & Interm. & Pitcher & Linear & Interm. & Pitcher \\
\hline Del Norte & 439 & 4 & 439 & 1 & 3 & 1 & 0 & 442 \\
\hline Siskiyou & 94 & $4 \dagger$ & 96 & $2 \dagger^{*}$ & 0 & 0 & $4 *$ & 94 \\
\hline
\end{tabular}

$\uparrow$ One plant had both 3-cotyledons and an intermediate first leaf

* One plant had both intermediate first and second leaves 


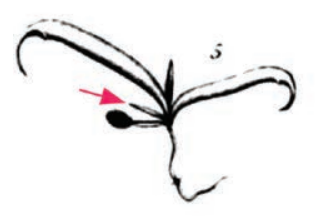

Goebel (1891)

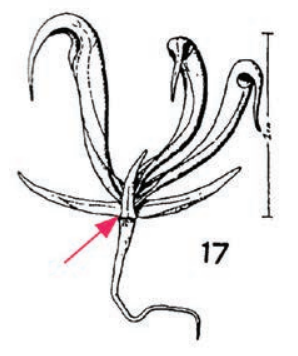

Lloyd (1942)

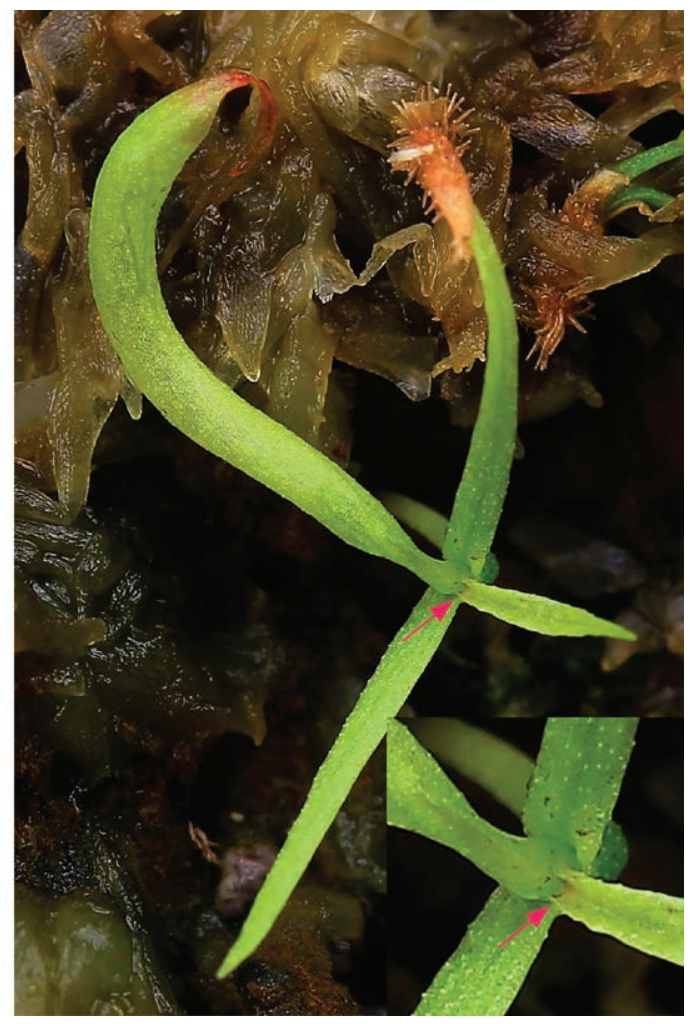

Figure 1: Darlingtonia seedlings. The drawing from Goebel (1891) shows the linear-lanceolate leaf shorter than the two cotyledons, one of which still has a seed attached. The Lloyd (1942) drawing shows the first true leaf as if it was a third cotyledon. The leaf should have been drawn enclosed by the cotyledons as shown by the image on the right. The inset details how the linear-lanceolate first true leaf wraps the apex within the cotyledons. Red arrows in photo indicate apex.

a pitcher. Another 1\% started late, producing two linear-lanceolate leaves or an intermediate-type leaf as the second leaf. The exact numbers observed in this study are not necessarily indicative of the species as a whole since the seeds were collected from only a few individuals at each location.

As part of this study, I confirmed Harry Tryon's (personal communication) observation that the Mt. Eddy area, Siskiyou County seeds were larger with denser trichomes than seeds from coastal California, Oregon, and the Sierra Nevada of California (see Brittnacher 2014). It is not known if the differences in the seeds are the result of a unique difference in that population and whether a larger study would see differences in the seedlings.

The results of this study show the first true leaf in typical Darlingtonia seedlings appears to be an unmodified ancestral leaf. It is similar to the leaves of its relative Roridula gorgonias without the glandular hairs (see photos linked at http://cpphotofinder.com). The first true leaf not being a carnivorous leaf or derived from a carnivorous leaf in Darlingtonia appears to be unique among pitcher plants. Sarracenia and Heliamphora, sister genera to Darlingtonia, produce a juvenile pitcher as the first true leaf. Among non-relatives, the first true leaf in Cephalotus is a unifacial pitcher-derived 

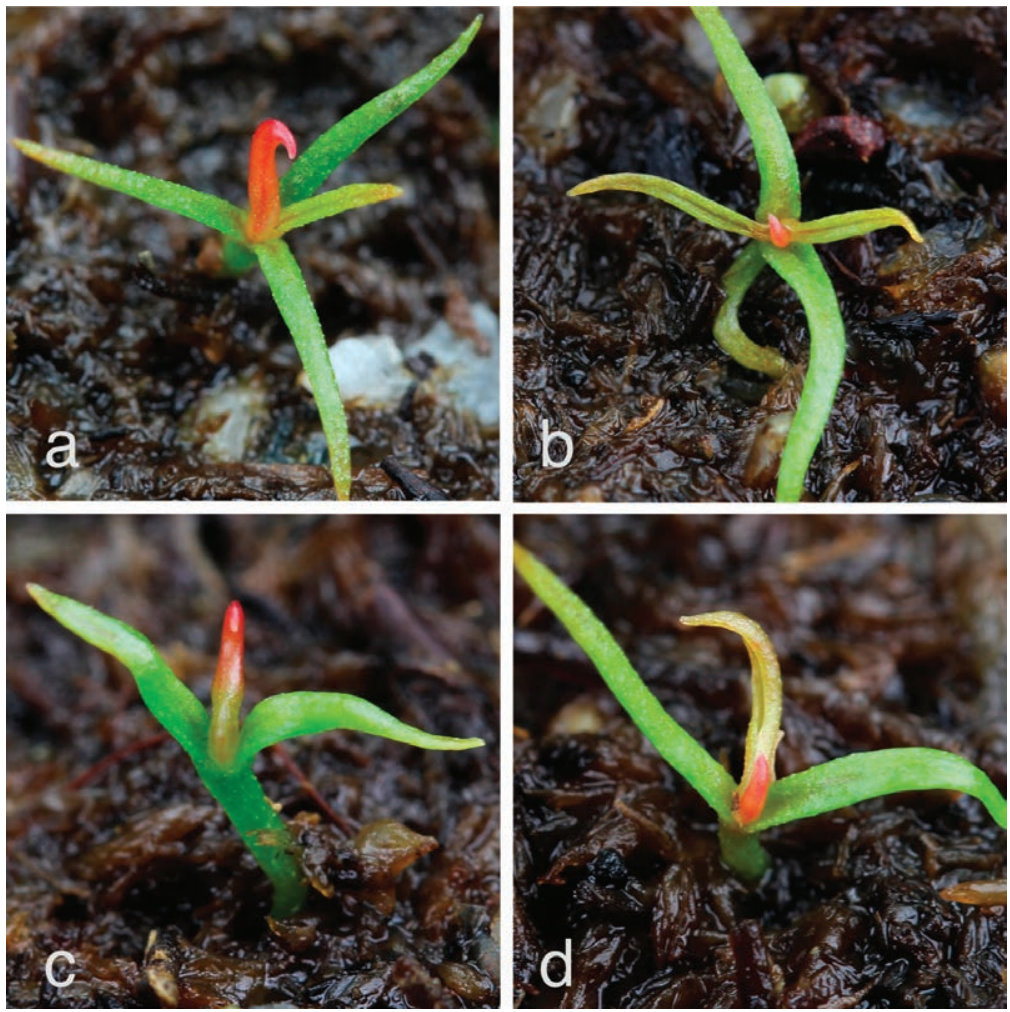

Figure 2: Darlingtonia seedlings with non-typical leaves: (a) three cotyledons instead of two, (b) second true leaf not a pitcher, (c) first true leaf a pitcher, (d) first true leaf intermediate between a linear-lanceolate leaf and a pitcher.

phyllode (see Brittnacher 2013) although a detailed study may show it can be either a pitcher or phyllode. Depending on the species or hybrid, the first true leaf of Nepenthes can range from recognizable adult-like pitchers to flattened leaf-like pitchers (see Brittnacher 2014).

Acknowledgement: I thank Mike Wang for seeds from two of the Del Norte Co. populations.

References

Brittnacher, J. 2013. Evolution -- the Oxalidales Carnivore. http://www.carnivorousplants.org/cp/ EvolutionOxalidales.php, accessed 4 December 2013.

Brittnacher, J. 2014. Supplement to the non-carnivorous leaf of Darlingtonia californica. http:// www.carnivorousplants.org/cpn/articles/CPNv43n2p40_42.supp.pdf.

Franck, D.H. 1976. Comparative morphology and early leaf histogenesis of adult and juvenile leaves of Darlingtonia californica and their bearing on the concept of heterophylly. Bot. Gaz. 137(1): 20-34.

Goebel, K. 1891. Pflanzenbiologische Schilderungen. Part 2, V. Insektivoren. Marburg. Lloyd, F.E. 1942. The Carnivorous Plants. Chronica Botanica, Waltham, MA. 


\section{CARNIVOROUS PLANT NEWSLETTER}

Journal of the International Carnivorous Plant Society

Volume 43, No. 2 June 2014

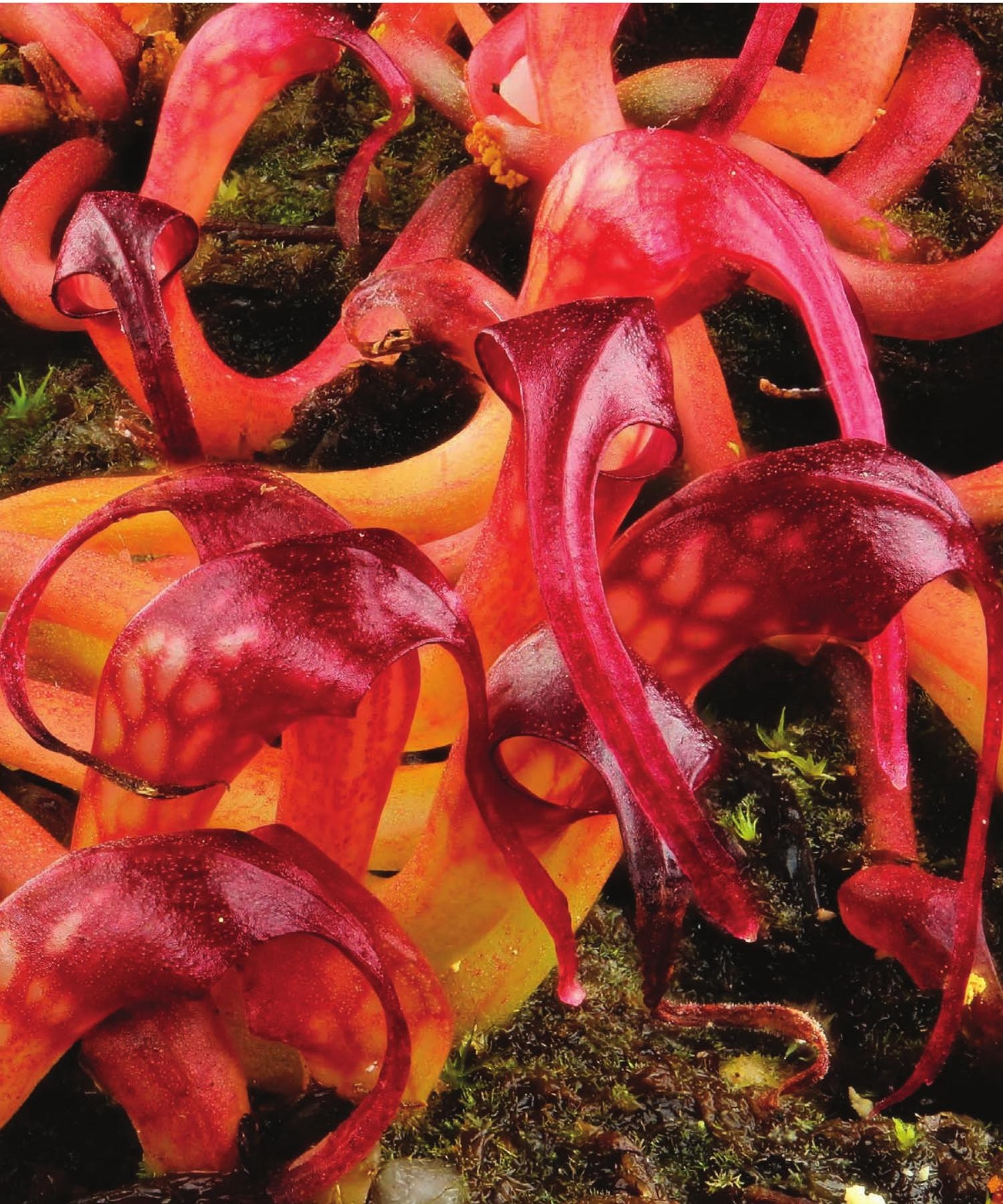




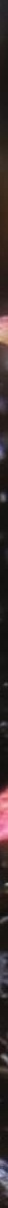

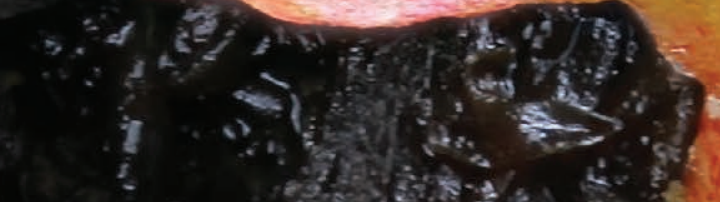

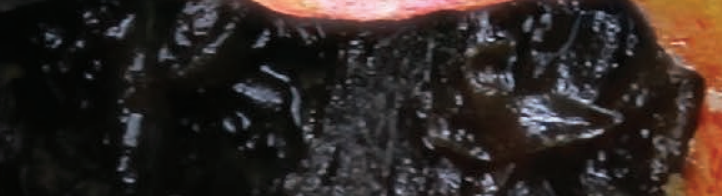

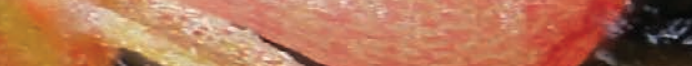

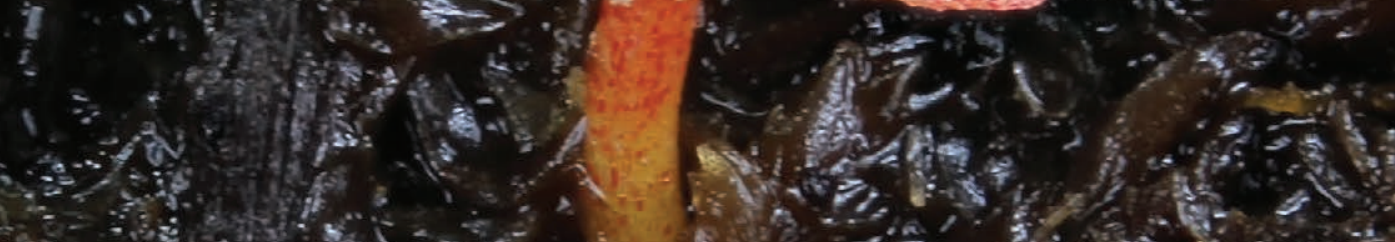

(n)

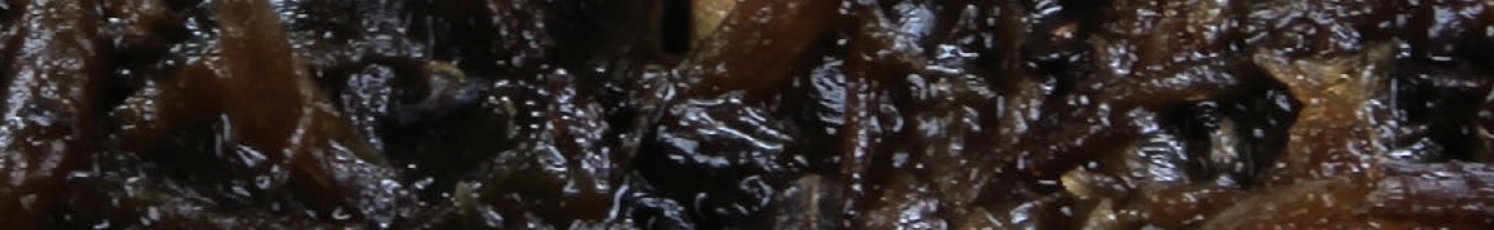

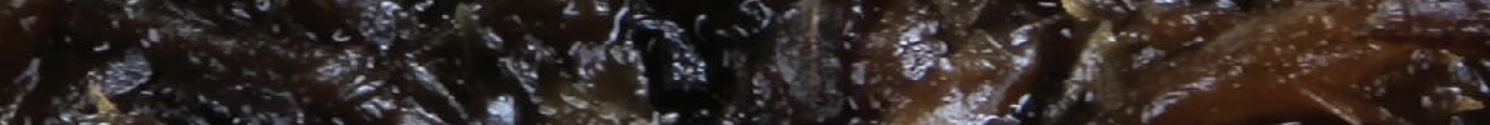
(c)

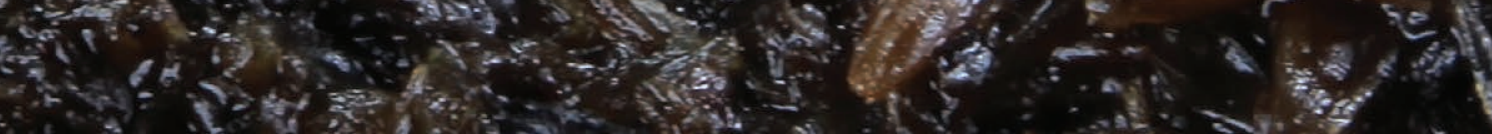

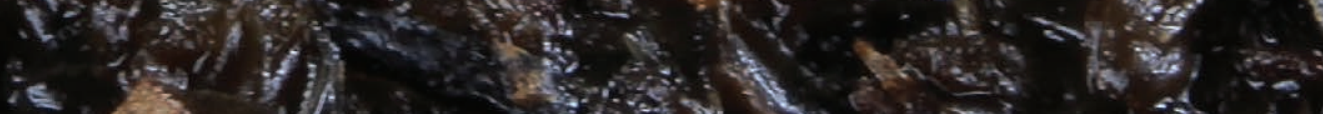




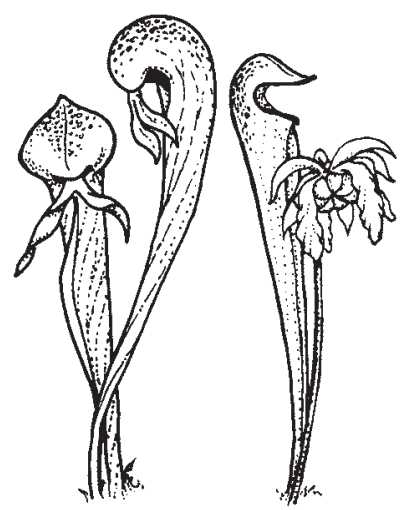

\section{CARNIVOROUS \\ PLANT \\ NEWSLETTER}

Journal of the International

Carnivorous Plant Society

www.carnivorousplants.org

Volume 43, Number 2
June 2014

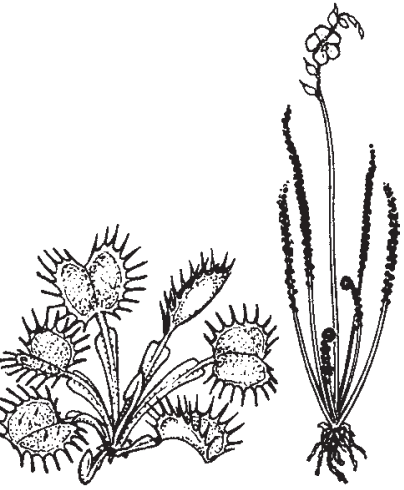

Front Cover: Juvenile pitchers in eight-month-old Darlingtonia californica seedlings. The image is a 22 photo composite by John Brittnacher. Article on page 40.

Back Cover: Darlingtonia californica seedling with an incompletely closed pitcher. This is the second true leaf. The first true leaf is the linear-lanceolate leaf under the newest forming pitcher. The image is a 29 photo composite by John Brittnacher. Article on page 40.

Carnivorous Plant Newsletter is dedicated to spreading knowledge and news related to carnivorous plants. Reader contributions are essential for this mission to be successful. Do not hesitate to contact the editors with information about your plants, conservation projects, field trips, or noteworthy events. Advertisers should contact the editors. Views expressed in this publication are those of the authors, not the editorial staff.

All correspondence regarding dues, address changes and missing issues should be sent to the Membership Coordinator at the ICPS. Do not send such correspondence to the editors. Checks for subscriptions should be made to the ICPS in US funds. Dues for 2014 are \$35 for the first year of membership; renewals are \$30 per year.

International Carnivorous Plant Society, Inc.

2121 N. California Blvd., Suite 290

Walnut Creek, CA 94596-7351, USA

icps@carnivorousplants.org

President

Secretary/Treasurer

Board Member

Board Member

Board Member

Board Member

Administrator

Seed Bank Manager

CPN Editors

Managing Editor

Editor

Editor

Science Editor

Science Editor \& Cultivar Registrar

\author{
Marcel van den Broek, marcel@carnivorousplants.org \\ Richard Myers, richard@carnivorousplants.org \\ Greg Bourke, Conservation Director, greg@carnivorousplants.org \\ Richard Nunn, richardnunn@carnivorousplants.org \\ Jan Schlauer, jan@carnivorousplants.org \\ Bob Ziemer, bob@carnivorousplants.org \\ Cindy Slezak, cindy@carnivorousplants.org \\ John Brittnacher, john@carnivorousplants.org \\ editor@carnivorousplants.org \\ Bob Ziemer \\ Barry Rice \\ Djoni Crawford \\ Fernando Rivadavia \\ Jan Schlauer
}

Date of effective publication of the March 2014 issue of Carnivorous Plant Newsletter: 12 March 2014.

The ICPS is the International Cultivar Registration Authority (ICRA) for the names of cultivated carnivorous plants according to the International Code of Nomenclature for Cultivated Plants. Send relevant correspondence to the ICPS, Inc.

Carnivorous Plant Newsletter is published quarterly in March, June, September, and December by the ICPS, Inc., 2121 N. California Blvd., Suite 290, Walnut Creek, CA 94596, USA. Periodicals postage paid at Richmond, CA and additional mailing offices. Postmaster: Send address changes to ICPS, Inc., 2121 N. California Blvd., Suite 290, Walnut Creek, CA 94596, USA. Printed by Allen Press, Inc., 810 E. 10th Street, Lawrence, KS 66044. Logo and masthead art: Paul Milauskas. (C) 2014 Carnivorous Plant Newsletter. All rights reserved. ISSN \#0190-9215 